\title{
Oğuz Atay’ın Düşünsel Arka Planı: “Günlük”
}

\section{Zeliha KAPUKAYA ${ }^{1}$}

\section{$\ddot{O} z$}

Oğuz Atay, 1970 sonrası Türk edebiyatında adından sıklıkla söz ettiren ve Türk edebiyatında ilk post-modern roman olarak bilinen Tutunamayanlar'ın yazarı olarak geniş kitlelerce tanınmış bir romancıdır. Tutunamayanlar romanının yayımlanmasından sonra birbiri ardına roman, öykü, tiyatro oyunu türünde eserler neşreden Atay, hayatının son yedi yılında tuttuğu günlüğü ile de dikkat çekmektedir. Yazarın Günlük adıyla neşredilen eseri, diğer eserlerini oluştururken geçirdiği süreci ayrıntılı bir şekilde vermektedir. Bu nedenle, yazarın söz konusu çalışması Atay’ın düşünsel ve edebî kimliğini ortaya koyacak zengin veriler sunmaktadır. Oğuz Atay, Türk edebiyatının romancılığı ile öncü yazarlarından olması bir yana yaşanan toplumsal olay, kavram ve tespitlere yönelik keskin eleştiriler de yapmaktadır. Yazarın eleştirilerini açıça Günlük'te görmekteyiz. Eserlerinin fikrî altyapısını oluştururken farklı kaynaklardan beslenen yazar, Günlük'te okuduklarından, izlediklerinden, etkilendiği yazar ve filozoflardan sıklikla bahsetmektedir. Ayrıca tamamlamaya firsat bulamadığı ve “Türkiye'nin Ruhu” adını vermeyi planladığı eserinin ayrıntıları yine Günlük'te yer almaktadır. Bu makalede Oğuz Atay'ın Günlük'ü, yazarın otobiyografisine, fikrî ve edebî kimliğine önemli katkılar sağlayan yönleriyle incelenmiştir.

Anahtar Kelimeler: Oğuz Atay, Günlük, Aydın, Tutunamayanlar, Postmodern Roman

\section{Oguz Atay’s Intellectual Background: Günlük}

\begin{abstract}
Oğuz Atay is a widely known novelist as the author of the Tutunamayanlar, known as the first post-modern novel in Turkish literature, which is frequently mentioned in post-1970 Turkish literature. After the publication of the novel Tutunamayanlar, Atay published novels, stories and plays one after the other and attracts attention with his diary which he kept in the last seven years of his life. The work of the author, published under the name of Günlïk, gives a detailed account of the process he undertook in creating his other works. Therefore, the author's work provides rich data to reveal Atay's intellectual and literary identity. Oğuz Atay is also one of the pioneering writers of Turkish literature and makes sharp criticisms of social events, concepts and determinations. The author's criticisms are clearly seen in the Günlïk. The author, who is nourished from different sources while creating the intellectual background of his works, frequently mentions what he reads, watches and influences the writers and philosophers in the Günlük. . In addition, the details of his work, which he has not had the chance to complete the Project and he planned to give the name of "Türkiye'nin Ruhu" are also in Günlük. In this article, Oguz Atay's diary was examined in terms of its important contributions to the autobiography, intellectual and literary identity of the author.
\end{abstract}

Key Words: Oğuz Atay, Günlük, Intellectual, Tutunamayanlar, Postmodern Novel

Atıf İçin / Please Cite As:

Kapukaya, Z. (2020). Oğuz Atay’ın düşünsel arka planı: “Günlük”. Manas Sosyal Araştırmalar Dergisi, 9(1), 552-561.

Geliş Tarihi / Received Date: 21.12.2018

Kabul Tarihi / Accepted Date: 28.03.2019

\footnotetext{
1 Dr. Öğr. Gör. - Balıkesir Üniversitesi Türk Dili Bölümü, zelihakapukaya10@hotmail.com 


\section{Giriş}

Türk insanını içinde yaşadığı tarihsel sürece tanıklık eden kesimlerin içinde edebî şahsiyetler özel bir yer teşkil eder. Zira tanık olmanın ötesinde yaşanan tarih dönemeçleri inceleyen, yorumlayan; insana, topluma ve hayata bir aydın sorumluluğuyla yaklaşan bu şahsiyetler, yaşamın verdiklerini sanat prizmasından geçirerek yeniden insana ulaştırır. Özellikle 20. yüzyıl gibi dünyanın kabuk değiştirdiği, buna paralel olarak çok sayıda fikir ve sanat akımın ortaya çıtı̆ğı bir yüzyılda, insan ve toplumun dönüşümü, roman başta olmak üzere edebî türlerin hemen hepsinde işlenmiştir. Dünya ile birlikte Türk Edebiyatında da bu yüzyılda modernizm ve postmodernizm; konu, tema, üslup ve anlatım teknikleriyle varlığını göstermiştir. Bunlardan modernizm adı verilen büyük estetik dönüşüm 20. yüzyllda Batı edebiyatında bütünüyle gerçekleşmiş, Türk edebiyatında da özgün roman örnekleriyle yer almıştır. Joyce, Kafka, Proust, Musil, Woolf, Faulkner gibi sanatçıların çalışmalarıyla farklı boyutlara taşınan post-modernizm ise Türk Edebiyatı'nda kendi sınırlarını aşamamış, gerektiği gibi varlık gösterememiştir. Türk edebiyatı için sıra dışı kurgusu ve biçim denemeleriyle Oğuz Atay'ın Tutunamayanlar romanı modernden postmoderne evrilen yolda bir avangard roman olma vasfina bütünüyle sahiptir. Söz konusu estetik dönüşümü gerçekleştiren Atay, diğer eserleriyle de postmodern romanın edebiyatımızda yerleşmesine büyük katkı sağlamıştır.

Çok yönlü bir aydın ve romancı olan Oğuz Atay (1934-1977); bilimden edebiyata, sanattan dile, felsefeden psikolojiye kadar geniş bir ilgi alanına sahiptir. Edebiyat tarihimizde özel bir yer teşkil eden yazar, eserlerinde batı ve doğu uygarlıkları arasında kalmış, kimlik arayışı içindeki Cumhuriyet Dönemi aydınının fikrî ve ruhsal düzlemdeki sorunlarını sıklıkla dile getirmiştir. Atay, özgünlüğün ayrıntıda olduğuna inanmış ve bu inancını eserlerine uygulamıştır (TBEA, s. 2003).

Tutunamayanlar (1971-1972), Teblikeli Oyunlar (1973), Bir Bilim Adammnn Roman (1975), Eylembilim (1998) adlı romanlarıla, Korkuyu Beklerken (1975) adlı öyküsüyle ve Oyunlarla Yaşayanlar (1985) adındaki tek tiyatro eseriyle Türk edebiyatındaki yerini pekiştirmiş olan Oğuz Atay, ilk baskısı 1987 yllında yapılan Günlük üu ile de edebiyat araştırmacıları ve okuyucuları için önemli otobiyografik malzeme sunmuştur.

Günlükler, deneme türüne yakınlıklarıyla düşüncelerin açık ve serbest olarak ifade edildiği edebî türler arasındadır. Roman ve hikâye türünde kullanılan çerçeve anlatım tekniğinde sıklıkla kullanılır. Dünya düşünce ve edebiyatına yön vermiş pek çok ismin günlügü, otobiyografik öneminin yanında birer felsefî metin olmaları yönüyle de önemli bir kaynaktır.

Makalemizin konusu olan Atay'ın Günlük'ü; yazarın şahsî, edebî ve düşünsel kimliğini yakından tanımamızı sağlayacak zengin ayrıntılarla doludur. Atay'ın roman yazma tekniğine dair bilgilerin, yazmayı tasarladığı eserler hakkında notların, daha önce yazdığı eserler üzerine detayların ve anektodların yer aldığ1 eserde, Atay'ın okuduğu, etkilendiği yazar ve düşünürlerin izini de sürmek mümkündür. Bütün bunların ötesinde Atay'ın günlüğünü önemli kilan bir unsur, eserde yazarnn fikrî yönünü ve yazarlığını ortaya koyan bilgilerdir. 25 Nisan 1970 tarihinde başlayıp 29 Ocak 1977 tarihine kadar yazmaya devam ettiği Günlük'te, adım adım ölümün ayak seslerini duyan bir insanın, her şeyden öte hayalleri ve yazmayı planladığı eserleri olan bir yazarın varoluş mücadelesi görülür.

Oğuz Atay, günlüğünde öncelikle bir roman yazarı olmakla birlikte okuyan, düşünen ve eleștiren bir şahsiyet olarak karşımızdadır. Eserde söz konusu süreçleri yaşarken aldığı notlar Oğuz Atay portresini daha yakından tanımayı kolaylaştırır. Atay'n günlügüne kaydettiği notları; yazarın Insan ve Toplum Üzerine Düs̆̈̈nceleri, Aydin Eleștirisi; Tasarlar, Romanlar ve Eleştirileri, Etkilendiğ Yaz̧ar ve Düsünürler şeklinde çeşitli başlıklarla sınıflandırmak mümkündür. Atay'ın romanları ve roman eleştirilerine dair notları ise yazarın edebî yönünü ortaya koymaktadır.

\section{İnsan ve Toplum Üzerine Düşünceleri}

Oğuz Atay'n eserlerinin arka planında birey ve bireyin sorunları önemli yer tutar. Dünyayı ve Türk toplumunu şekillendiren kapitalist sistem içinde sıkışan insanımızı, yalnızlığıyla, tarihine, kendisine ve toplumuna yabancilaşmasıyla, bir oyun kurgusundaki yaşamıyla romanlarının temel olgusu yapan Atay, günlüğünde de Türk insanının geçmişten günümüze taşıdığı karakteristik özelliklerini bir düşün adamı ve sanatçı kimliğiyle analiz etmeye çalısıır.

Oğuz Atay, günlügünde Türk insanının öncelikle birey olamama problemi bulunduğunu düşünür. Atay' a göre bu problemin temelinde birtakım dinî, tarihî, idarî, sosyal ve kültürel sebepler vardır. Yazar, bu problemin dinî ve tarihî nedenlerini açıklarken Osmanlı toplumundan günümüze devreden "birey sorunu"na dair düşüncelerini sıralar. Atay’a göre insanımızın "birey olamama" sorununun geçmişten bu 
yana fazla değissiklik göstermeyen toplumun hayat görüşüyle sıkı ilişkisi vardır. Osmanlı toplum felsefesinin temelinde bu dünyanın geçiciliği ve insanın dünyaya karşı bir varlık teşkil etmemesi temel belirleyendir. Başka bir ifadeyle; hayatın temel gerçeği olan ölüm karşısında insanın dünyaya dair yapabileceği fazla bir şey yoktur. Bu fanilik düşüncesi hayatımızın her köşesini şekillendirmiş; mimarîden sanat, toplum ve felsefeye kadar hayatımızın her alanına sirayet etmiștir. Atay'ın ifadesiyle Evimiz̨in bahçesinde, sokăğn köșesinde tek. mezarlar olmal. Her sey geçicidir. Belgeler gereksizdir, unutulacak ayrntilar yaz̧mak anlamsızdir. Belki de unutmak esastır (Atay, 2003, s. 90-92). Unutmanın esas olduğu ve insanın ölüm karşısındaki çaresizliğinin, faniliğinin her an hatırlatıldığı bir toplumsal yapıda, beraberinde getirdiği sorumluluk düşüncesiyle insan birey olamamaktır.

Atay, Osmanlıların birey olamayan insanı ciddiye almadığını belirtirken toplumu yönlendiren bütün değişimlerin devlet eliyle gerçekleştirildiğini hatırlatır. Bu anlayışın Cumhuriyet döneminde de devam ettiğini ifade eden yazar, devletin halkı adına düşünme, düşündüklerini fililiyata geçirme ve toplumsal dönüşümleri gerçekleştirme işlevlerini de yerine getirdiğini vurgular. Atay, bir anlamda devletin toplum mühendisliği yaptığını anlatmak için şu mizâhî örneği verir: Tek parti döneminin Ankara valilerinden Nevzat Tandoğan'ın yakalanarak yanına getirilen solcu gence: 'Bu memlekete komünistlik gerekirse onu da bir. getiriviz: Sana ne oluyor?” demiştir ( Atay, 2003, s. 90-92).

İnsanımızı, kapalı sistem içinde ezen anlayışa ve gelenekçi toplum yapımıza dair eleştirilerini sürdüren Atay; tiyatronun, felsefenin, eleştirinin, resmin olmadığından yakınır. Yazar, bu yoksunlukların hem sebebi hem de sonucu olarak yine "birey olamama" problemini görmektedir. Zira aşılmaz bürokratik engellerle insanımızın toplumda birey olarak var olması bilinçli veya bilinçsiz şekilde engellenmiştir. Meseleyi sanat üzerinden irdeleyen yazara göre eski toplumuzda özgün sanat yoktur. Yalnız usta-çırak ilişkisi içinde taklit

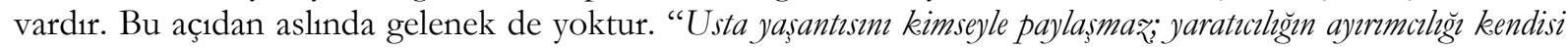
ile birlikte ölür. Ne rubun ölümsü̈liüg̈̈ ne de canl dünyann gürültüsü duyulur diyen Atay, taklit ve geleneksizllik sorunlarının temelinde birey olamama sorununun yattığını düşünür. Osmanlı toplum yapısını şekillendiren kapalı sistemin batıya olduğu kadar doğuya da kapalıdır. Bu kapalılı̆̆ın temeli de yine "dış dünyaya karşı beslenen korkular"dır (Atay, 2003, s. 92). Yazar dolayısıyla korkunun insanımızın bireysel yönlerini şekillendirmesine müsaade etmediği sonucuna varır.

Atay'n, günlügünde Türk insanı ve toplumuna dair tespitlerinden biri de yukarıda değindiğimiz gibi hayatımızı birtakım korkuların şekillendirdiği düşüncesidir. Tarihimizi, toplumumuzu ve dolayısıyla insanımızı şekillendiren korkulardan kurtulmak için boyun eğdirme yönteminin kullanıldığını ifade eden yazar, "ber yandan düsman saldrrss bekleme", "sarayn kaleye çevrilmesi", sarayn korkusu", kültür, matbaa, șïr, resim yani sanatın özgürlessmesi korkusu" gibi davranış ve korkuların sonucunun "yabancilaşma" olduğunu belirtir (Atay, 2003, s. 94). Böylelikle Atay, birey olamama-korku ve yabancılaşma kavramlarının birbiriyle nedensellik bağ1 içinde olduğunu vurgular.

Atay'ı roman ve karakter kurgusunda işlediği yabancılaşma kavramı ile birlikte yabancılaşmanın bir sonucu olan yalnızlık, ayrıca tüm bu sıkıntılarla bireyin başa çıkmasını sağlayan oyuna sı̆̆ımma davranışının kökeninde de geçmişten günümüze toplumsal hayatımızı yönlendiren korku olgusunun bulunduğu açıktır. Zira 1975 yılında yayımlanan Korkuyu Beklerken adlı öykü kitabında işlediği korku/yabancılaşma/yalmı̨̧lk imgeleriyle fikrî ve edebî düzlemde model aldığı Kafka etkisi açıkça görülür. Korku, yabancılaşma, oyun üçlemesinde, sanat bu nedenselliğin son halkasıdır. Çünkü sanat da nihayetinde bir oyundur. Muteber, dış dünyanın sahteliklerine karşı gerçekliği olan, insana sonsuzluğun kapılarını açan ve hayatı anlamlaştıran yönleriyle sanat; yabancılaşma ve yalnızlık karanlığındaki yazar (ve insan) için yegâne çıkış yoludur. Keza sanat ve oyun postmodernist romanciların sığındığı birer sığınaktır. Bilhassa modernizmin katı gerçekçiliğine karşı postmodern metin oyun kavramını merkeze koyarak okuyucusunu gerçeklik çemberinin dışına çıkarmak ister. Bunun yanında oyun işlevsel olarak okuyucu ile yazarı birbirine yaklaştırır (Emre, 2006, s. 115-116).

Atay, günlügünde geçmişten günümüze hayatımızı şekillendiren korkularımızın suç ve ceza kavramları ile ilişkilendirerek yine Türk insanı için sıklıkla bir kültürel vasıf olarak kullanılan "hoşgörü" davranışının sosyal-psikolojik köklerine iner. Atay şöyle der: Müeyyideler hayatı zebir edecek kadar korkutmaludr; ama isyan ettirecek kadar kesin olmamahdir. Neyin ne olduğu, hangi suçn cezasinm ne kadar olduğu bilinmemelidir. Fakat herkes ber an suc işlediğini hissetmelidir ki başkaldiramasin. Her zaman suç işlediği balde kendisine taviz verildiğini bissettiügi için

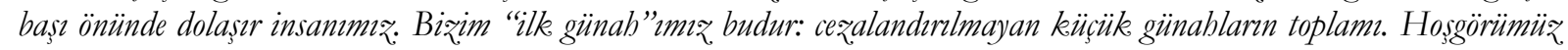

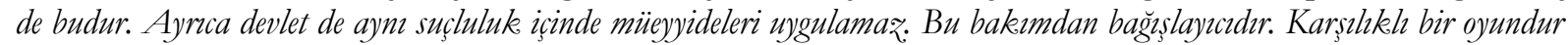
bu. Bağgşlanmayan tek suç, bu oyunu fark etmek, bu oyuna karșı ģıkmaktur. Gerçeği aramaktrr. Bilim bunun için 
tehlikelidir, felsefe bunun için teblikelidir, deneme bunun için teblikelidir, roman ve bikêye bunun için tehlikelidir...(A tay, 2003, s. 94-96). Yazar insanımızdaki suçluluk psikolojisini en güzel romanlarında anlatır. Hakikat diye sunulan, değer diye insanın önüne konulan kavramları sorgulayan Atay'ın roman kahramanları, topluma ve yerleşik otoriteye göre uyumsuz ve suçludur. Modern insanın iç dünyasındaki uyumsuzluk ve kargaşayı, yani suç ve cezayı irdeleyen yönleriyle Atay, roman kurgusunun alt yapısını günlügüündeki notlarıyla ortaya koymuş, hem fikrî açıdan hem de roman sanatı bakımından Dostoyevski ile olan bağını göstermiştir.

Oğuz Atay, günlüğünde halkı ve korkunun gölgesinde yaşayan edipleri karşıt kutuplarda konumlandırarak bir oyun mantığ1 içinde hayatımızda var olan korkuların halkın sözlü geleneğinde pek fazla yer almadığını belirtir. Zira yazılı olan korkunun onayından geçtiği için yazılı olmayan dilden dile dolaşan sözlü halk ürünleri daha özgürce ifade edilmiştir. Bu nedenle sözlü halk ürünleri halkın gerçekte ne düşündüğünü ne hissettiğini ortaya koyması açısından önemlidir (Atay, 2003, s. 96).

Oğuz Atay, diğer yandan Türk halkının, kendisini sınırlayan ve bireyselleşmesini engelleyen zincirlere rağmen evrensel olduğunu düşünür. Çok uluslu ve dolayısıyla çok kültürlü Osmanlı toplumu, yapısından dolayı farklılıklara ve evrenselliğe açık bir toplumdu. Bu kültür kodlarından gelen Türk insanı, kendine yabancılaşmış ve kendisine sahip çıkacağı beklentisindeki aydına rağmen evrenselliğini devam ettirmektedir. Atay; taklitçilikle, ön yargılarla Türk insanının evrenselliğinin bilinçsizce baltalandığını belirtir. Diğer taraftan insanımızda büyük bir potansiyel olduğuna ve bu gücünü kullanamadığına dikkati çeker. İnsanımızdaki potansiyel, açığa çıkarılmalı ve organize edilmelidir. Bu görev en başta aydına ve toplum adına söz sahibi olan kişilere düşmektedir. Atay’a göre özünde kimseye düşman olmayan Türk insanı, bütün eksikliklerine rağmen dünyayı tanımak ve çağdaş dünyanın bir parçası olmak istemektedir. “ Biz, geri kalmus bir ülke değiliz, fakir kalmus bir soyluya benzetilebiliriz ancak”" diyen Atay, Türk insanı ile Avrupalı ve Amerikalıları kıyaslamaktadır. Yazar, Batı insanının kendi dışındaki milletlere temelinde samimiyetsiz, soğuk, mesafeli, istismar ve sömürü duygusuyla yaklaştığını belirtir (Atay, 2003, s. 130-240).

Kısaca Atay günlüğ̈ünde birey ve topluma dair düşüncelerinde en başta insanımızın birey olamama problemini tespit eder ve sonrasinda bu problemin temelinde var olan nedenleri siralar. Toplumu ve insanımızı hayata karşı çekingen olmaya iten, pasifleştiren korkuların, Osmanlı kültür ve sanatındaki taklit ve geleneksizlik sorunun temelinde de bulunduğu tespitini yapan yazar; korku, suçluluk psikolojisi, yalnızlaşma ve yabancılaşma sorunlarına değinir. Türk insanı ve toplumsal yapısının Atay'ın bakış açısıyla bir tahlili diyebileceğimiz günlügün bu bölümleri Oğuz Atay'ın fikir adamlığı boyutunu anlamak açısından orijinal yaklaşımlar sunar.

\section{Aydın Eleştirisi}

Modernitenin bir sonucu olarak kendine ve toplumuna yabancılaşmış, yozlaşmış aydın pek çok edebî ve düşünsel eserin işlediği konulardandır. "Kendi toplumuna onulmaz" bir uzaklıkta olan "entelektüel", sözün gücünü keşfederek sözden eylemin alanına yol almaya, ait olduğu toplumu yeniden inşa etmeye" doğru gider (Bermann, 2001, s. 31).

Aydın kavramı Yeni Türk Edebiyatı'nın hemen hemen her türünde üzerinde sıklıkla durulan kavramlarındandır. Oğuz. Atay'da Aydın Olgusu adlı kısa çalışmasında Yıldız Ecevit, aydın kavramını; düşünen, duyumsayan ve elestiren, varoluşu temeli tinsel etkinliğinde yatan insan olarak tanımlar. Toplumsal bilmeceye çözüm bulmadan evvel, kendini bulma uğraşısındadır; çelişkilerini, komplekslerini aşmayı deneyerek kendisini sorgulayan kişi, aydın bireydir (Ecevit, 1989, s. 96).

Oğuz Atay'ın bütün eserlerinin temel problemlerinden olan kendisine ve toplumuna yabancılaşmış aydın tipi, günlüğünde de özellikle ele alınmaktadır. Roman kahramanlarının kişiliklerine dair tasarı ve analizlerinde Türk insanını anlama çabasında yazar, toplum önüne aydın kimliğinde dolaşan bu tiplerin noksanlıklarını göz önüne sermeye çalışır.

Atay, öncelikle insanımızı ve aydın kavramını karşılaştırarak Türk toplumunun kapalı bir sistem içinde sıkıştığını ve var olmaya çalıştığını açıklar. Halkın yaşantısı yazara göre canlı ve gerçektir; fakat burjuva olmaya çalışan, aydın olma özentisi içinde çırpınan az̧ınlık ölü bir hayat sürmektedir. Yani bu sözde aydının yaşamı bir bakıma taklit ve oyundur. Halk, şehrin kenarına itilmiş yerlerde, kırsal alanlarda canlı bir hayat sürerken bu oyunlarla yaşayan güruh "büyü̈e caddelerde, yükesek yapılar içinde suskunluk içinde" "mış" gibi yaparak hayatını sürdürmektedir. Bu durum toplumda kapalı bir sistem oluşturmaktadır. Yazara göre şehir hayatının müeyyideleri olmayan bu kapalı sistemde, insan ya yok olup gitmekte ya da yaşantısı̨̆lklarmı örtmeye çalışmaktadır. Oğuz Atay, eserlerinde sıklıkla kullandı̆̆ı “oyun” kavramını halkına yabancılaşan ve aydın geçinen bu küçük azınlığın davranışlarını açıklamakta kullanır. Partiler, araba yarışları, uyuşturucu 
maddeler, sefahat âlemleri bu kesimin oyunlarıdır. Batıl ağabeylerinin kötü birer kopyaları olan bu güruh, ülkede bir turist gibi yaşar (Atay, 2003, s. 102).

Oğuz Atay'ın kahramanlarında yazarın aydın eleștirisinin yansımalarını görmek mümkündür. Zira Atay'ın kahramanları, kendilerine özgü bir ses yaratabildiklerinde "taşralı", içselleştirmek için epey zaman harcadıkları Avrupa kültürünün temel kavramlarıyla konuşmaya başladıklarında ise "taklit" bir ses olarak kalırlar (Oğuz, 2009, s. 31).

Atay'ın sözünü ettiği, geçmişte hayatımıza daha fazla hâkim olan bu kapalı sistemde insanımız dünyanın farkında değildi. Yaşadığımız çağ ise beraberinde getirdiği özgürlük söylemleriyle insanı ezen, bütün değerleri alt üst eden "müktesabattyla" korkunç bir hale gelmiştir. İnsanımızın mazi özleminde, geçmişi "Kaybolan Cennet" gibi görmesinin kökeninde de bu durum yatmaktadır (Atay, 2003, s. 102). İnsanımızın geçmişten günümüze hayat içinde var olamama ikilemindeki trajedi, yaşama karşı gerçekçi bir tutum takınmasını zorlaştırmakta, bütün iyi ve güzel şeylerin eskide var olduğu algısını güçlendirerek toplumun geleceğe dair umut ve hayallerini baltalamaktadır.

Atay; günlügünde aydınımızın bölünmüşlüğüne, ikilemlerine ve tutarsızlıklarına da değinir. Aydınımızın bu trajikomik durumunu, Eylembilim adlı eserinden $S$. karakterinin müzik anlayışı üzerinden örneklendirir. Zira aydınların bir bölümü kendini alaturka ve halk müziği sevmemekle yüceltir, bir kısmı da tersiyle yani iki müziği toleransla karşılayarak ve kendini halktan yana hissederek kendilerine geniş görüşlülük atfetmektedir. Bu durumun edebiyatta da mevcut olduğunu ifade eden yazar, aydın kavramına yönelik eleştirilerini, doğu-batı karşıtlığından yola çıkarak devam ettirir (Atay, 2003, s. 272-274). Oğuz Atay, öncelikle doğu ve batı medeniyetlerinin taban tabana birbirinden farklı uygarlıklar olduğunu ifade eder. Ona göre en başta mantıkî olarak bu iki uygarlığın birbirini kavraması hemen hemen imkânsızdır. Batılıların Doğuyu tanımak istemelerindeki amaç, tamamen sömürü niyetleriyle ilgilidir. Batı sömürebilmek için Doğu'nun zayıf yönlerini anlar; fakat özünü kavrayamaz. Diğer yandan onların mantı̆̆ ile kendimizi derinlemesine anlamak bütünüyle yanlış bir iştir. Onların mantığı ile insanına yaklaşan kimliksizleşmiş, özenti Türk aydınının gittikçe bir ruh tembelliğine düştügünü gören yazar, bu aydın tipinin aydın kavramının ihtiyaç duyduğu orijinaliteye asla ulaşamayacaklarını vurgular (Atay, 2003, s. 184-186). Atay'ın hedef tahtasındaki aydın tipi, son dönem Osmanlı aydını ile birlikte, Cumhuriyetin değerleriyle yetişmiş; fakat yine kendine özgü kimlik geliştirmemiş ait olduğu toplumun kültür köklerine "tutunamamış" aydınlardır.

Oğuz Atay'ın ideal aydını, Bir Bilim Adammın Roman adlı eserinin ana figürü olan Mustafa İnan'ın kimliğinde tarifini bulur. Bu aydın tipi, birey toplum sentezini gerçekleştirmiş, Doğu-Batı kültür ikileminin üstesinden gelmiş, "tolerans, bilgi ve dürüstlük sözcüklerini kendine ilke edinmiştir. Atay'ın aydını; ütopik olmayan, ruhsal değerlerdeki tüm yozlaşmaya karşın geleceğine inandığı aydındır (Ecevit, 1989, s. 96).

Genel anlamda "insanın kendisiyle hesaplaşması", "varoluşsal boşluk ve kimlik bunalımı", "DoğuBatı kültürel karşıtlığının insana ve topluma yansıması" Oğuz Atay'ın bir üçleme olarak kabul edilen Tutunamayanlar, Teblikeli Oyunlar ve Oyunlarla Yaşayanlar adlı eserlerinde yoğun olarak işlenir. Bilhassa "Oyunlarla Yaşayanlar" adlı eseri, bir tiyatro eseri olmasından dolayı Atay'ın "oyun" metaforunu gerçek bir "oyun” metninde işlemesi ile tiyatro-edebiyat ilişkisinin iyi bir örneğini verir (Atay, 2003)

Genel olarak, Oğuz Atay'ın Türk aydınını temsil eden kişi ve kesimlere bakışı olumsuzdur. Atay'ın sürekli eleştirdiği aydın tipi; tutarsız, kendine, tarihine, toplumuna yabancılaşmış, özentilik ve kararsızlık girdabına tutulmuş, fikir çilesi çekmeyen, "sorumluluk" duygusundan uzak tiplerdir. Oğuz Atay'n gözünde bu kadar olumsuz niteliklere sahip Türk aydını, varoluşçuların yaklaşımıyla "Türk kültür ve toplumuna ait özleri mi yoksa varoluşları nedeniyle mi bu durumdadır?". "İnsanımızın, toplumumuzun ve tarihimizin herhangi bir suçu yok mudur?”, sorularını akla getirir. Sanırız ki var olan aydın tablosundan her kesim sorumludur. Gerçek bir aristokrasi ve burjuva kesiminin olmadığ1; düşüncenin, sanatın itibar görmediği; halkın aydınlanmaya talepkâr olmadığı bir sosyo-kültürel ortamda yüzyıllardır ideallerde yaşatılan aydın nasil var olabilir?

\section{Tasarıları, Romanları ve Eleştirileri}

Oğuz Atay, günlüğünde aldığı notlarla yer yer yazacağı eserlerinin planlarını yazmış, romanlarında, hikâyelerinde kullandığı veya kullanacağı karakterlerin analizini yaparak bu karakterleri nasıl daha derinleştireceğine dair düşüncelerini kaleme almış, bazen de çıkacağı televizyon programına hazırlıklarını not etmiştir. 
Atay'ın günlüğünde en fazla kritik yaptı̆ğ ve üzerinde düşündüğü Teblikeli Oyunlar romanı ve romanın başkarakteri Hikmet'tir. Günlüğundeki notlardan anlaşıldığına göre yazarın bahsi geçen romanı ve romanın karakterlerini oluştururken Erich Berne'nin "Games People Play” adlı eserinden etkilendiği anlaşılmaktadır. Dostoyevski'nin Yer Altından Notlar adlı eseri de yine etkilendiği, romanlarının hem kurgu hem de tema ve karakterizasyonunda model aldığ1 eserler arasındadır (Atay, 2003, s. 14). Örneğin; Sevgi, Hikmet, Bilge gibi pek çok karakter nasıl derinliğine verilebilir kaygısıyla alınan notların, yan okumaların günlükte uzun uzun yer aldığı görülmektedir.

Atay, günlüğünde kendisini görmeyen okuyucu ve eleştirmenlere de değinir. Atay'ńn hedefindeki "yabancı kitapları kapışan; ama kendisinden haberi olmayan okuyucu ve eleştirmenleri beklemek yazara göre aptallıktır (Atay 2003, s. 222). Yazarın okur tarafindan anlaşılma hassasiyeti aynı zamanda günlük tutma gerekçesidir. Bunu "Kimse dinlemiyorsa beni-ya da istediğim gibi dinlemiyorsa- günlük tutmaktan başka çare kalmyyor. Canmm insanlar! Sonunda bana bunu da yaptnnz:" cümleleriyle ifade etmektedir (Atay, 2003, s. 4). Sesinin arzu ettiği gibi duyulmadığından şikâyetçi olan Atay'ın günlügü, bir bakıma kendi sesine kulak verdiği, kendi kendini kritik ettiği romanlarında sıkça kullandığ1 iç monolog ve bilinç akışlarıyla sesini, sanatını, fikirlerini kuyucuya duyurmak istediği bir çalışmadır. "Ben Burdayım." diyen ve sesini duymayan okur-yazar-çizer takımından sitemle bahseden yazar, pek çok yazarın kaderi olan öldükten sonra anlaşlmaktan ya da hiç anlaşılmamaktan şikâyetçidir (Ecevit, 2007, s. 1)

Aslında dönemin eleştirmenleri Atay’a kadar o kadar da kayıtsız kalmamıştır. Atay’la Türk romanı hakkında röportaj yapan Konur Ertop buna bir örnektir. Söz konusu röportajdan notlar alan Atay, röportajında edebiyatımıza dair orijinal tespitlerde bulunur. Konur Ertop’la yaptığı söyleşinin notları Atay'ın edebiyat eleştirisi açısından fikirlerini ortaya koyma olanağı verir. Atay, öncelikli olarak Türk romanının meselesi kişilik olduğunu düşünür. İnsanımız bir kişilik verme savaşındadır ve edebiyatçılarımız bunun önemini kavrayamamaktadır. Ayrıca romancılarımız "kendisiyle hesaplaşma" diye bir kavramdan habersizdir, romanımı bu nedenle düzmece ve diyalektik gibi büyük kavramların arkasına sığınan cüceler ordusudur. Yazarın dikkat çekici bir eleştirisi de dönemin sosyalist Marksist bir anlayışla roman yazar köy romancilarınadır. Atay bu konuda "Köylünün sefil yaşayışı olgusu büÿ̈̈k roman yazmayı gerektirmę"” der. Yazar, bu tarz roman yazarlarını "balka büyüle doğrular adina yalan söyleyen, kültü̈rsǚ, gerçeğ̈ sez̧emeyen, derinlikten yoksun, havuz edebiyatçsı, esnaf zibniyetine sahip, dïreysiž, halkin acllarm ve sefaletini sömüren sifatlarıyla niteler. Bunların içinde gerçekleri okuyarak, düşünerek, kendi bilinci ile sezen, kafası ve yüreği genç olanların bulunduğunu da belirtir. Atay, " Sabte eleştirmenlerin koltuk değneklerine dayanarak yürïyenlerin, edebiyat reklam

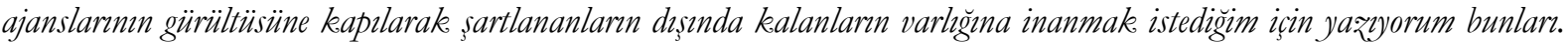
Belki Kemal Tahir'in dediği gibi günde 24 saat romanc olmann gereğini duyanlar ya da duyacak olanlar vardr." sözleriyle reklam ajanslarılla sürekli toplumun gözünün içine sokulan yazarları ve edebiyatı metalaştıran zihniyeti eleştirir (Atay, 2003, s. 224).

Oğuz Atay, bilhassa günlüğünde her ne kadar sosyalist geçinen yazarlara sıkı eleştiri oklarını firlatsa da kendisi bir dönem bu çevrenin içinde bulunmuştur. Atay'ın kısa süreli bir yayın hayatına sahip Olaylar dergisini çıkardığı döneme kadar koyu bir Marksist olduğunu; ancak dergisinde yaşananların etkisiyle sol çevreden hızla uzaklaştığını belirtelim ( Ecevit, 2007, s. 120). Yazar günlüğ̈nde, gençlik yıllarında mensubu olduğu sosyalist çevreleri en başta samimiyetsizlikle suçlamaktadır. Atay şu ifadeleri kullanir(Atay, 2003, s. 138):

Türk solu gec kalkar, çünkü bir gece önce sabaha kadar içmiştir. Bu insanlardan Türk halke bir şey beklememeli. Ückâğgtçllkkla ne devrim olur ne de ümmet-i İslam kurtulur. Bunlar çürüyen et, dökülen diş gibidirler. Bayrak yaptıklar inançlarna rağmen, aslnda inancsızdorlar. Kim bangi kapıdan ekmek yiyorsa, o kapınn kulluğunu etmektedir. Bunlar Osmanl Imparatorluğu'nun mirasinn kötü bölümü olan kapıkulu

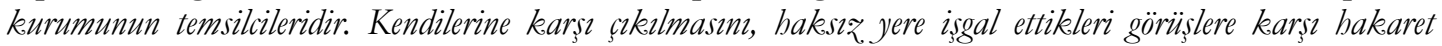

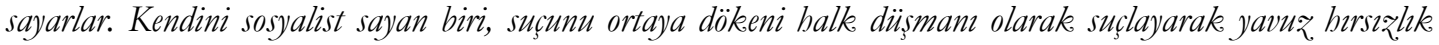
oynar. Kendini kapitalist olarak. ilan eden birinin serveti, fabrikast yoksa böyle birine berkes güler; baydi oradan culsuz derler, zï̈̈̈̈rt kapitalist olur mu? Nedense kendilerine kimse ebliyet sormamaktadir. Olsa olsa sosyalizme sempati duyan, yani özel deyimiyle sempatizan saynlması gerekenler ortalğ̆ kasip kavurmaktadrlar.

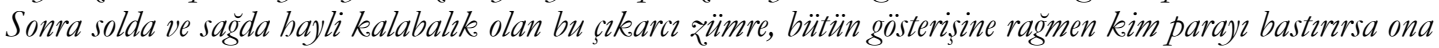
bį̧met etmektedir. Ele güne karş̧, bele sağglara karşı ayıp olmasin diye de kabahatler örtbas ediliyor.

Yukarıdaki pasajda Atay'ın zaman içinde sosyalist kesimlere ne denli cephe aldığı, bir zamanlar mensubu olduğu bu çevrelerden ne kadar fazla uzaklaştığı görülmektedir. Atay'ın hayatının sonraki 
dönemlerinde ise kendi kabuğuna çekilerek daha öznel bir çizgi benimsediği bilinmektedir (Ecevit, 2007, s. 473).

Atay'n günlügünde yazarın o dönemde edebiyat çevrelerinde adından sıkça söz ettiren "İkinci Yeni Akımı" hakkında da görüşlerini belirtir. İkinci yenicileri "yaşlarr, kültürleri ve dünya görüssleri gelismeye elverişli olmayan; fakat duyduklar ve sezdikleriyle gerçeküstü ve geceke ötesi seyleri yer yer yakalamuslar; sonunda hepsi bir yana dağılmışlar" olarak algiladığını belirten yazar, önemli olanın ülkede her çeşit akımın atılımın iyi ya da kötü çıması olduğunu ifade eder. Atay'n burada dikkat çektiği husus, sanat ve kültür hayatımızda çok sesliliğe ve evrenselliğe olan ihtiyaçtrr.

Oğuz Atay günlüğ̈̈nde yazmayı planladığı eserleri üzerine aldığı notlara ve tasarılara da yer vermektedir. Atay'ın, o dönemde henüz yayınlamadığı "Teblikeli Oyunlar" adlı romanının bazı bölümlerine dair notlar, Geleceği Elinden Alınan Adam" başlıklı hikâyesi ve Yıldız Kenter'in de henüz taslak halini incelediği "Hayat Bir Oyundur" isimli tiyatro eserinin metin kısmından bazı parçalar günlüğünde yer almaktadır. Ayrıca yazarın tamamlamaya ömrünün vefa etmediği Türkiye'nin Rubu adlı eserine dair ön çalş̧maları da günlüğünde mevcuttur (Atay, 2003, s. 122-128).

Türkiye'nin Rubu, Atay'ı üç bölüm olarak yazmayı tasarladığ1 ve bu bölümlere "Devlet, Toplum ve İnsan” adlarını vermeyi düşündügü kitabıdır. Yazar, yapacağı çalışmayı klasik bir inceleme kitabı olmaktan ziyade, karmaşık kurgulu, sorunlara çok yönlü yaklaşan, ana temayı ön planda tutan bir eser olarak yazmayı planladığını ifade etmektedir. Kurgusal bir anlatı metni olacağını söyleyen Atay, çalışmasında determinist bir tarih anlayışı ile hareket edeceğini; ancak tarihî olayların ve şahısların ele alınışında sosyal-psikolojinin bakış açısını kullanacağına dikkat çekmektedir (Atay, 2003, s. 232).

Günlük, Oğuz Atay için gerçek manasıyla yazmayı planladığı eserlerinin karalama tahtasıdır. Eserlerinin kurgu, plan ve otokritiğini yaptığı bölümler Atay'in geçirdiği süreçleri yakından takip etmek açısından dikkate değerdir. Eser, bilhassa karakterlerini kurgularken yazarın konu, tema ve sembolleri nasıl derinlemesine düşündüğ̈nü, irdelediğini ve kritik ettiğini anlamak açısından zengin veriler ihtiva etmektedir. Adeta Günlïk, yaşamı yazdığı eserler gibi bir roman derinliğinde geçen Atay'ın hayatının bilinç akışı, iç monolog gibi yöntemlerle anlatıldığı bir metindir. Ayrıca büyük hevesle başladığı Türkiye'nin Rubu adlı eserine dair Atay'ın aldığı notlar ve yaptığı ön çalışmalar eserin tamamlanması noktasında okuyucuda bir beklenti oluşturmaktadır.

\section{Etkilendiği Yazar ve Düşünürler}

Oğuz Atay; günlügünnde okuyan, inceleyen, düşünen bir yazar ve fikir adamı olarak geniş bir bilgi ve kültür atlası üzerinde dolaşmaktadır. Atay'ın okuduğu, romanlarında konu, sembol, karakter kurgusunda etkilendiği ve kimi zamanda bütünüyle model aldığ1 yerli-yabanc1 önemli sayıda yazar ve düşünür bulunmaktadır.

Oğuz Atay, okuduğu ve düşüncelerinden etkilendiği Fanon, Oscar Lewis, Spengler, Belinsky, Eddington gibi yazar ve düşünürlerin devrim ve toplum hakkındaki eserlerinden yola çıkarak Türk toplumuna dair çıkarımlarda bulunur. Yazar, Fanon'un Fransız devrimine ilişkin dikkat çeken bir tespitine de yer vermektedir. Fanon; devrimi gerçekleştiren lümpenproleterya" sınıfının devrim aracıllğı ile kendi gözleriyle ve tarih önünde yeniden itibar kazandıklarını düşünür ve onlar için "Şehir alevler içinde yanarken lanetliler de bu atește temįliğe ulassyorlar, güzel ve kutsal oluyorlar." ifadelerini kullanır. Devrim figüranlarının tarih önünde bu şekilde iade-i itibar elde ettiği, bu durumun farklı zaman ve ülkelerde de benzer şekilde gerçekleştiği dikkate değer bir tespittir. Ayrıca yazar Fanon'un lümpenproletarya yüceltmesini Tutunamayanlar ve Teblikeli Oyunlar adlı eserlerinde kullandığını ifade ederek fakirliğin kültürüne dair tespitlere Oscar Lewis'te de rastladığını vurgular. Atay, günlüğünde Oscar Levis'in Sanchežin Cocuklar, İste Hayat adıyla Türkçeye çevrilen kitabından aldığ1 notlara da yer vermektedir (Atay, 2003, s. 252-254).

Günlük'te yer alan ilginç tespit ve yorumlardan biri de entropi kavramı ile ilgilidir. Atay, İngiliz matematikçi, fizikçi ve astronom Eddington'un The Nature of The Physical World adlı eserinden bahseder. Bu kitaptan hareketle fizikteki entropi meselesini irdeleyerek Kafka'nın dehşetinde entropiyi sezmesinin payı olduğunu belirtir. Entropi, "Termodinamik yasalara göre, bir sistem içinde enerji azalmasindan ötürü, her seyin durması" olarak tanimlanir (Atay, 2003, s.248). Atay, insanın sezgileri vasitasiyla gelecekte olacak bu sicak ölümün dehşetini duyabileceğini, "debumanizasyon" denilen "insansızlașma, insanîlikten uฉaklassma ve kopma" nın Kafka’nın insanlarında görüldüğünü belirterek şöyle devam eder (Atay, 2003, s. 250): 


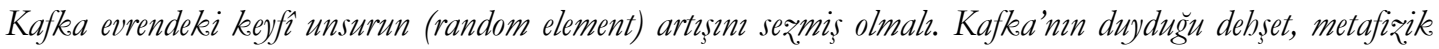
bir debşset değildi yani. Son derece düzenli görünen; ama ashinda akell diş ola toplumda, gerçeküstü ya da dişkeyfilikler yer alır. Insanlar evrendeki bas așăgr gidisin farkindadirlar; sanki bu yüzden bir yere ulaşlamayacağın (olumlu bir yere) bilirler. Aslinda K. (romanlarn kabramani) olumlu bir tiptir; ümittidir, savaşır kazanamayacağm bildiği halde. Bu asil bir savaştrr. Ümitsizliğe karşı savaştır. Entropiye karşı

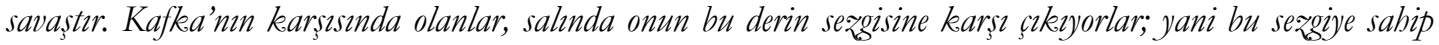
olmadiklar için onu yanlıs yorumluyorlar.

Oğuz Atay, yukarıdaki tespit ve yorumlarıyla Kafka’yı bir bilim adamı dikkati ile anlamaya çalıstığını göstermektedir. Yazar'in Tutunamayanlar, Teblikeli Oyunlar, Oyunlarla Yaşayanlar gibi eserlerinde işlediği bir facia korkusuyla hayatı yaşayan, bilindik bir sona sürüklenen tiplerinin kökeninde Kafka'nın kahramanları gibi entropik sezgiler bulunmaktadır. Bu durum Atay'daki çok belirgin Kafka izlerini görmek açısından dikkat çekicidir.

Oğuz Atay, Oyunlarla Yaşayanlar adlı oyununu yazarken Games People Play isimli eseri detaylica incelemiş ve aldığ1 notlara günlügünde yer vermiştir. Atay, günlügünde oyunu "gerçek yaşantmmn gerçek iliskkinin yokluğunda onun yerine gę̧en șey", görünür karş̧llklı iliskilerin rubsal ilişkiyle birlikte ve çelişik durumda var olması" olarak tanımlamaktadır. Atay'a göre simirlamalar ve çekinmeler oyun oynamaya neden olur. Yazarın Erich Berne 'den alıntıladığı oyun kavramında dikkat çektiği noktalardan biri bütün kötü oyunlarn, iyi düzenlenemeyen zamanin yol açtğ̆ can sıkintısinn sonucu olduğudur. Zira insanın zamanı düzenleme yollar1: vakit gę̧irme, ayin, oyun, yakinllk kurma şeklindedir (Atay, 2006, s. 118).

Atay bir fikir adamı ve romancı olarak elbette ki yerli romancılarımızdan da etkilenmiştir. Günlügünde yer alan notlarından Oğuz Atay'ın Halit Ziya'yı ayrıntılı şekilde incelediği ve yazarı hem fikrî yönüyle hem de kendi romancilı̆ı açısından bir model aldığ1 görülmektedir. Gerçek manasıyla Türk romanının kurucusu olarak değerlendirebileceğimiz Halit Ziya, Atay'a göre Türkiye Taribinde önemli bir dönüm noktası olan Batı'ya açulsşn insanm vermekle bugünkü Türkijyenin de önemli bir bölümünü aydnlatmak. bakımından ilginç bir edebiyațuder (Atay, 2003, s. 190).

Bir televizyon söyleşisinde Atay, Halit Ziya'nın romanlarını ve insanlarını kedi duyarlllığına çok yakın bulduğunu söylemiştir. Bu yakınlığı TRT'deki söyleşisinin notlarının yer aldığ1 günlüğünde de belirtmektedir. Tutunamayanlar'daki tiplerin Halit Ziya'nın Kırı Hayatlar, Mai ve Siyah romanlarındaki tiplerle olan duygu benzerliğini vurgulayan yazar, söz konusu tiplerdeki hesaplaşmaların kendisine yakın geldiğini söyler. Sürekli bir hesaplaşma içindeki Oğuz Atay kahramanlanı, kendi benzetimiyle tıpk1 Halit Ziya'nın trajik roman kahramanları gibi "Zayıf iradeleri ve önleyemedikleri kaderlerinin sonlarmı" yaşamaktadır (Atay, 2003, s. 186).

Oğuz Atay günlüğünde Kemal Tahir' e dair aldığı notlara da yer vermektedir. Kemal Tahir, Atay'nn beğendiği romancılar arasındadır. Kemal Tahir, Osmanlı'dan Cumhuriyet'e batıllılaşma kavramını, Türk insanının kültürel ve sosyo-politik değişimini; kapsamlı, derinlemesine ve bir aydın duyarlıllı̆ı ile irdelemiş (Tahir, 1992); romanlarında da işlemiştir. O dönemde Kemal Tahir'e yapılan "sürekli görüşlerini değiştirdiği” eleştirisi Atay'ın dikkatini çekmiş, yazar bu eleştiriye cevap verme ihtiyacı hissetmiş̧ir. İnsanın değişmesinin bir gelişme olduğu düşüncesini benimseyen Atay, Kemal Tahir'in, kendisine ters gelen görüşlerini değiştirdiğini herkesten önce kendisinin ifade etmesinin çok önemli bir nokta olduğunu vurgulamıştır. Atay'a göre bu bir "hesaplaşma"dır ve insanımızın hesaplaşmaya çok ihtiyacı vardır (Atay, 2003 , s. 184) . Atay, Kemal Tahir gibi insanımız da bir yandan kendisiyle öte yandan da toplumu ve tarihiyle hesaplaşabilme cesaretini gösterebilmeli, bu vesileyle "birey olma" yolunda kendini geliştirmelidir.

Atay, Kemal Tahir'den yola çıkarak irdelediği hesaplaşma kavramını en başta roman kahramanlarının kişiliğinde işlemiştir. Tutunamayanlar'ı Selim'i, Turgut'u, Teblikeli Oyunlar romanının Halit’i ve diğer kahramanları kendisiyle hesaplaşan, bu süreçte kendisiyle konuşan, tartışan karakterlerdir. Atay'n diğer eserleri gibi günlüğü de baştan sona kendisiyle, toplumuyla, tarihiyle hesaplaşan bir insanın ruh dünyasını ele verir. İnsan aslında kendisiyle farkında olarak veya olmayarak sürekli hesaplaşmakta, hesabını veremediği yerlerde oyuna sığınmaktadır. Elbette kendisine, toplumuna, tarihine, topyekûn hayata hesap verme sorumluluğu olan aydının hesaplaşması bambaşka bir önem arz etmektedir.

\section{Sonuç}

Bütün yönleriyle Oğuz Atay'ı Günlük ü; Atay biyografisinin ve sanatının yakından anlaşılması için zengin veri sunmaktadır. Türk romanının postmodernizm dönemecinde önemli bir yerde bulunan Atay romanları; kurgu, karakterizasyon, tema, üslup ve teknikleri bakımından öncü yapısıyla dikkat çekmektedir. 
Romanlarındaki pastiş, parodi, ironi, montaj, similasyon ve kitsch gibi teknik ve kavramların avangard kullanımıyla Atay Türk edebiyatında çı̆̆ır açmıştır. İşte Türk edebiyatına bu katkıları veren Atay romanlarının teknik alt yapısının gelişim aşamaları günlügünde görülebilmektedir. Diğer taraftan Atay'ın beslendiği kaynaklar ve romanlarının arka planı günlüğünde açıkça ortaya konmaktadır. Ayrıca yazarın insan, sanat, toplum, aydın ve bütünüyle hayata dair düşünceleri eserde yer almaktadır. Bilhassa sürekli eleștiri oklarını yönelttiği olumsuz tipteki Türk aydınının eksiklerini hayatı ve eseri ile tamamlayan bir fikir ve sanat adamı olarak Atay’n günlüğü onun "karalama tahtası"dır. Ayrıca yazarın etkilendiği, okuduğu, takip ettiği yerli-yabancı düşünür ve sanatçların kimler olduğu, eserden elde edilebilecek ayrıcalıklı veriler arasındadır. Yazarın çağdaş bilimin ortaya koyduğu bilimsel ve sosyolojik verileri fikrî ve edebî açılımlarıyla kullanması da önemli bir noktadır. Özellikle Atay'ın, Kafka temalarına getirdiği yorum ve entropi kavramı hakkındaki tespitleri dikkat çekmektedir. Her şeyden öte Günlük'ün son sayfalarında kendi tabiriyle "geleceği elinden alınan adam" Atay'ın hayat ve ölüm arasındaki trajik varoluş mücadelesi okuyucunun tanıklığına sunulmaktadır.

\section{Kaynakça}

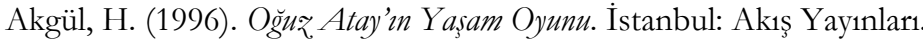

Atay, O. (2003). Günliik. İstanbul: İletişim Yayınları.

Atay, O. (2003). Oyunlarla Yaşayanlar. İstanbul: İletişim Yayınları.

Atay, O. (2003). Eylembilim. İstanbul: İletişim Yayınları.

Atay, O. (2003). Bir Bilim Adammm Romanı. İstanbul: İletişim Yayınları.

Atay, O. (2016). Tutunamayanlar. İstanbul: İletişim Yayınları.

Berman, M. (2001). Katı Olan Her Şey Bubarlassyor: Modernite Deneyimi, çev: Ümit Altuğ ve Bülent Peker. İstanbul: İletişim Yayınları.

Ecevit, Y. (1989). Oğuz Atay'da Aydm Olgusu. İstanbul: Ara Yayıncilik.

Ecevit, Y. (2007). “Ben Burdayım...” Oğuz. Atay'mn Biyografik ve Kurmaca Dünyası. İstanbul: İletişim Yayınları.

Emre, I. (2006). Postmodernizm ve Edebiyat. Ankara: Anı Yayıncillk.

Moran, B. (1994). Türk Romanna Eleștirel Bir Bakess 2. İstanbul: İletişim Yayınları.

Oğuz, B. (2009). Oğuz, Atay'da Yazarllk Kurumunun İflası ve Edebî İntihar (Doktora Tezi), İstanbul Bilgi Üniversitesi, Sosyal Bilimler Enstitüsü, İstanbul.

Tahir, K. (1992). Notlar/Bathllasma. İstanbul: Bağlam Yayınları.

TBEA (2003). Tanæimat'tan Bugüne Edebiyatçlar Ansiklopedisi, 1, 136-139, İstanbul: YKY.

\section{EXTENDED ABSTRACT}

Oğuz Atay is one of the most widely read, debated and avant-garde figures of Turkish literature after 1970. Especially his work titled Tutunamayanlar is one of the cult novels of Turkish literature. In addition to his novels, Atay has also published works in the genre of story and theater. In addition to these works, the diary of the author, who lost his life at a young age, continues to hold until the last time and summarizes the last seven years of his life, is a valuable resource for Oğuz Atay's biography. The study, which was published under Günlük, contains the notes written between 5 April 1970 and 29 January 1977. In the notes where the data on how the intellectual and technical infrastructure of his works are prepared, the formation process of Oğuz Atay's works can be followed. In other words, how Atay edited characters and events while writing his works in his diary; it is possible to see who are the authors and thinkers who are reading, influenced and followed. In addition to this, it is a study that draws daily attention in order to understand Oğuz Atay's critiques and sociological inferences and evaluations. Oğuz Atay's diary are discussed under the titles of "The Author's Thoughts on Human and Society; His Designs, Novels and Critics, Criticism of Intellectuals; Influenced by The Authors and Thinker”. Oğuz Atay's evaluations and critiques on Turkish people and society are based on ideas that have changed from past to present, on values that should and should not change. The author, in particular, touched upon the individual and social problems created by the capitalist system, which has shaped Turkish society for several centuries. Atay emphasized the following problems faced by Turkish people: "alienation", "non-individuality", "degeneration ", "intellectuals-public relations", "dilemmas created by east-west culture", "problems caused by overhead practices ", " past and future debates "... On the subject of social criticism, the topics covered in the course are "closed system" and "traditional society structure". The author, frequently emphasizes that the problem of "not being an individual" lies at the root of these problems. In Oğuz Atay's intellectual criticism, his thoughts emphasizing the importance and value of being intellectuals who are not alienated from society in real terms and have exceeded their contradictions and complexes have been put forward. Briefly, the type of intellectuals targeted by Atay is who was raised from the beginning 
of the history of Turkish Westernization to the Republic with the values of enlightenment philosophy; but they did not develop their own identity, they could not "hold onto ine the cultural roots of the society in which they were individuals". These issues, which the author dealt with in an essay style and in a very sensitive mood in his diary, are reflected in his characters in his novels and other fictional works. The ideal intellectual of Oğuz Atay appears as a personified in the identity of Mustafa İnan, the main figure of his novel Bir Bilim Adammin Romam. The ideal intellectual who found his description in his teacher Mustafa Inan; he must have achieved the synthesis of individual-society, overcome the East-West cultural dilemma, and "adopted the words of tolerance, knowledge and honesty. Atay's diary clearly shows the process of character editing and the characteristics of the characters. Oğuz Atay's diary presents rich data in order to understand his intellectual identity closely with his designs, novels and criticisms of the publishing world of the period. Atay also includes notes and designs on the works he plans to write in his diary. Notes on some parts of Atay's novel Teblikeli Oyunlar which he has not published at that time, his story titled Geleceği Elinden Alman Adam, and some pieces from the text part of Hayat Bir Oyundur which Yildiz Kenter also examines in its draft form, are among the notes. The most prominent of these notes are issued death due to chance can not be found in his book Türkiye'nin Rubu (The Spirit of Turkey) belonging to the bill and are planned. Oğuz Atay also listed the names he read and influenced in his diary. It is seen that writers and thinkers such as Fanon, Oscar Lewis, Spengler, Belinsky, Eddigton are influenced by their thoughts about revolution and society, and that these figures start from the sociological determinations of these names especially in intellectual-individual-society. Atay read primarily Kafka from Western literature; it is clear that he benefited from his fiction and characterization. Atay also tried to understand Kafka with the attention of a scientist. For example, it has taken Kafka's concept such as dehumanization. The shadow of Kafka's heroes who have lived a life of fear of tragedy, is clearly seen in the origins of Atay's novels Tutunamayanlar, Teblikeli Oyunlar and Oyunlarla Yasayanlar. One of the interesting findings and interpretations in the Günlïk is related to the concept of entropy. The author mentions the entropic intuitions of these heroes and states that Kafka's perception of entropy is a factor in his horror. In his notes, Atay referred to Eddington, a British mathematician, physicist and astronomer, in his book The Nature of the Physical World, and discussed the entropy in physics with a novelist and scientist approach. As an intellectual and novelist, Atay was also influenced by local novelists. Halit Ziya and Kemal Tahir are among these names. In his diary, it is seen that Atay studied Halit Ziya in detail and the author took a model both in terms of his intellectual and his own novel. He also notes the notes he received about Atay Kemal Tahir. Because Kemal Tahir is one of Atay's favorite novelists. Atay points out that Kemal Tahir correctly understood and told the Turkish people and society. In short, in all these aspects, Günlük presents, in his own words, the reader's testimony of Atay's tragic struggle for existence between life and death and the author's intellectual background. 